\title{
PENERAPAN PEMBELAJARAN PROBLEM SOLVING PADA MATA PELAJARAN PENDIDIKAN KEWARGANEGARAAN UNTUK MENINGKATKAN KETERAMPILAN BERFIKIR DAN AKTIVITAS BELAJAR SISWA
}

\author{
Indria Kristiawan, Anselmus.J. E Toenlioe, Sulthoni \\ Pasca Sarjana Universitas Negeri Malang \\ e-mail: kristiawan_indria@yahoo.co.id
}

\begin{abstract}
Abstrak. Penelitian ini dilaksanakan untuk memperbaiki kualitas belajar siswa dalam cara berfikir dan aktivitas belajar, tujuan penelitian ini adalah untuk meningkatkan keterampilan berfikir dan aktifitas belajar siswa kelas VIII G SMP Negeri 1 Jabung. Penelitian ini merupakan penelitian tindakan kelas (PTK), terdiri dari dua siklus, setiap siklus terdapat empat tahap yaitu perencanaan, tindakan, observasi, dan refleksi. Pengumpulan data melalui observasi, catatan lapangan, lembar kerjasiswa, lembar observasi kemampuan berfikir, dan lembar observasi aktivitas siswa. Berdasarkan hasil penelitian dapat disimpulkan bahwa model pembelajaran problem solving dapat meningkatkan kemampuan berfikir dan aktivitas belajar siswa, dari siklus I ke siklus II secara keseluruhan kemampuan berfikir kritis dalam aspek pengkajian, intepretasi, penyelesaian dan pengambilan keputusan diperoleh $71 \%$ meningkat $3 \%$ dari siklus I. Aktivitas siswa dalam pembelajaran menggunakan model problem solving dapat membuat siswa lebih aktif dan kritis dalam hal memperhatikan, menjawab pertanyaan, bekerjasama, mempresentasikan jawaban, dan merespon jawaban siswa lainnya.
\end{abstract}

Kata kunci : pembelajaran problem solving, keterampilan berpikir, aktivitas belajar

\section{PENDAHULUAN}

Di sekolah, mata pelajaran Pendidikan Kewarganegaraan diberikan kepada siswa agar siswa memiliki bekal yang cukup dalam hak dan kewajiban sebagai warga negara baik secara teoritis maupun secara praktis.Secara teoritis, agar siswa dapat memahami tentang hak dan kewajiban sebagai warga Negara.Dikatakan secara praktis, agar siswa dapat melaksanakan sikap yang demokratis dan mampu menggunakan kemampuan berfikirnya secara maksimal serta dapat menentukan sikap dalam pengambilan keputusan. Kurikulum KTSP menegaskan bahwa pendidikan kewarganegaraan (PKn), merupakan salah satu mata pelajaran yang wajib di sekolah menengah pertama.PKn memiliki peranan dan berfungsi sebagai sarana pembinaan watak bangsa (nation and character building) dan pemberdayaan warga negara (Widyani, 2013). Berdasarkan fungsi dan peranan ini, maka PKn memiliki tujuan untuk membentuk dan membina subjek didik agar ; (1) memiliki kemampuan berfikir secara rasional, kritis, dan kreatif sehingga mampu mamahami berbagai wacana kewarganegaraan, (2) memiliki keterampilan intelektual dan keterampilan berpartisipasi secara demoktaris dan bertanggung jawab, dan (3) Memiliki watak dan kepribadian yang baik, sesuai dengan norma-norma yang berlaku dalam kehidupan bermasyarakat dan bernegara (Depdiknas,2006).

Berdasarkan dari hasil observasi pertama tanggal 03 November 2014 terhadap guru dan siswa SMP Negeri 1 Jabung diperoleh beberapa fakta dalam pelaksanaan pembelajaran $\mathrm{PKn}$, yaitu dalam kegiatan pembelajaran PKn masih mengandalkan hafalan, sehingga kurang menekankan pada aspek afektif dan psikomotor. Dalam proses pembelajaran masih berpusat pada guru( teacher centered approach), siswa kurang diarahkan untuk berfikir kritis, siswa tidak 
diajak untuk menemukan konsep tetapi hanya ditunjukkan konsep yang harus selalu diingat.

Pada observasi kedua pada tanggal 10 November 2014 di SMP Negeri I berdasarkan indikator berfikir kritis, ditemukan fakta dari 32 siswa hanya 10 siswa yang mengangkat tangan untuk menjawab pertanyaan guru, siswa merespon pertanyaan dari guru apabila ditunjuk tanpa disertai mengangkat tangan (dengan kata lain terpaksa menjawab), ketika siswa menjawab pertanyaan siswa kurang fokus dengan pertanyaan guru, serta kurangnya guru dalam mengarahkan siswa dalam befikir kritis sehingga mengakibatkan rendahnya kemampuan berfikir kritis siswa.Cara berfikir siswa yang tidak rasional, kemampuan pengambilan keputusan berdasarkan ego tanpa berfikir panjang, mengikuti dukungan yang banyak tanpa melihat benar atau salah, menilai sesuatu berdasarkan sudut pandang diri sendiri.Sehingga dapat disimpulkan kemampuan berfikir siswa terlihat belum maksimal yaitu kemampuan mengkaji masalah, interplasi masalah, penyelesaian masalah, pengambilan keputusan dalam memecahkan masalah.

Berdasarkan situasi tersebut, perlu adanya perubahan dalam pembelajaran PKn. Pembelajaran yang dapat menarik minat siswa agar memiliki pola pikir yang kritis, kreatif, konstruktif serta memiliki kebebasan untuk menemukan konsep sendiri sehingga konsep yang sudah ditemukan siswa mampu serta mudah untuk diingat oleh siswa. Oleh karena itu dilaksanakan pembelajaran dengan model pembelajaran Problem Solving pada mata pelajaran Pendidikan Kewarganegaraan sehingga mampu untuk meningkatkan ketrampilan berfikir serta aktivitas siswa. Adapun tujuan penelitian untuk meningkatkan keterampilan berfikirdan aktivitas belajar siswa kelas VIIIG SMP Negeri 1 Jabung.

Menurut Polya (dalam Hudojo, 2003:150), terdapat dua macam masalah pertama masalah untuk menemukan, dapat teoritis atau praktis, abstrak atau kongkret. Kita harus mencari variable masalah tersebut, kemudian mencoba untuk mendapatkan, menghasilkan atau mengkonstruksi semua jenis objek yang dapat dipergunakan untuk menyelesaikan masalah tersebut.Kedua masalah untuk membuktikan atau menunjukkan bahwa suatu pertanyaan itu benar atau salah atau tidak kedua-duannya.

Rahyubi (2012:252), menyatakan bahwa problem solving adalah upaya individu atau kelompok untuk menemukan jawaban berdasarkan pengetahuan, pemahaman dan ketrampilan yang dimiliki sebelumnya dalam rangka memenuhi tuntutan yang tak lazim. Aktivitas problem solving diawali dengan konfrontasi dan berakhir apabila sebuah jawaban telah diperoleh dan sesuai dengan kondisi masalah.Kemampuan pemecahan masalah diwujudkan melalui kemampuan berfikir dan pengambilan keputusan.Berfikir dan pengambilan keputusan adalah bagian dari berfikir yang meliputi berfikir mendasar, berfikir kritis, dan berfikir kreatif.

Berdasarkan karakteristik permasalahannya, problem solving memiliki tujuan mengarahkan siswa untuk berfikir kritis, analitis, sistematis, dan logis. Jadi dapat disimpulkan bahwa problem solving adalah proses berfikir dan pengambilan keputusan yang dilakukan individu atau kelompok untuk memecahkan masalah yang dihadapinya menggunakan prosedur pemecahan masalah yang tepat. Karena tanpa suatu prosedur yang tepat maka masalah tidak akan terpecahkan secara maksimal yang artinya dalam pemecahan masalah harus mencari dan memilih alternatif pemecahan yang cocok dengan jalan menggunakan pengetahuan dan pengalaman yang relevan serta menggunakan strategi kognitif.

Ennis (dalam Hassoubah, 2004:87), menyebutkan ada lima aspek berfikir kritis, yaitu ; 1) memberi penjelasan dasar (klarifikasi);

2) 
membangun keterampilan dasar; 3) menyimpulkan; 4)memberi penjelasan lanjut; dan 5) mengatur strategi taktik. berfikir kritis adalah berfikir secara beralasan dan reflektif dengan menekankan perbuatan keputusan tentang apa yang harus dipercayai atau dilakukan . Befikir kritis dipengaruhi beberapa faktor, seperti latar belakang kepribadian, kebudayaan, dan juga emosi seseorang.Berfikir kritis berarti melihat secara ragu-ragu terhadap apayang telah dilakukan dalam kehidupan. Berfikir kritis juga berarti usaha untuk meghindarkan diri dari ide dan tingkah laku yang telah menjadi kebiasaan.

Terdapat beberapa bentuk kecenderungan berfikir kritis, antara lain: 1) mencari pernyataan yang jelas dari sertiap pertanyaan; 2) mencari alasan; 3) berusaha mencari informasi dengan baik; 4) memakai sumber yang memiliki kredibilitas dan menyebutkannya; 5) memperhatikan situasi dan kondisi secara keseluruhan; 6) berusaha tetap relevan dengan ide utama; 7) mengingat kepentinngan yang asli dan mendasar; 8) mencari alternative; 9) bersikap dan berfikir terbuka; 10) mengambil posisi ketika ada bukti yang cukup kuat untuk melakukan sesuatu; 11) mencari penjelasan sebanyak mungkin apabila memungkinkan; 12) bersikap secara sistematis dan teratur dengan bagianbagian dari keseluruhan masalah; dan 13) peka terhadap tingkat keilmuan dan keahlian orang lain (Hassoubah, 2004:91)

Dari berbagai pernyataan tersebut dapat disimpulkan bahwa, berfikir kritis adalah sebuah proses yang terorganisasi dan jelas yang digunakan dalam kegiatan mental seperti memecahkan masalah, pengambilan keputusan, menganalisis asumsi dan melakukan penelitian ilmiah. Berfikir kritis mengarahkan siswa untuk memiliki kemampuan yang mengevaluasi secara sistematis bobot pendapat pribadi dan pendapat orang lain, menghadapi berbagai tantangan dengan cara yang terorganisasi, merumuskan pertanyaan inovatif dan merancang solusi pemecahan masalah yang valid dan ountentik.

Aktivitas berarti keaktifan, kegiatan, kesibukan. Aktivitas belajar adalah suatu kegiatan yang dilakukan oleh siswa pada saat proses pembelajaran untuk mencapai hasil belajar, Hamalik (2005: 171 Menurut Sardiman (2001: 93-95), bahwa dalam belajar diperlukan adanya aktivitas, tanpa aktivitas, belajar itu tidak mungkin berlangsung dengan baik.

Dengan demikian dapat disimpulkan bahwa didalam belajar perlu aktivitas, sebab pada prinsipnya belajar itu adalah berbuat, "learning by doing". Bahwa dalam pembelajaran siswa harus aktif, sedangkan guru hanya membimbing dan merencanakan pembelajaran yang akan dilaksanakan .

\section{Metode Penelitian}

Jenis penelitian ini menggunakan penelitian tindakan kelas. Skema yang digunakan dalam penelitian ini adalah model Kemmis dan Taggart (1998), yaitu model skema dengan menggunakan prosedur kerja sebagai suatu siklus spiral yang terdiri dari empat komponen: perencanaan, tindakan, observasi, dan refleksi yang kemudian diikuti spiral berikutnya. Pada Model Kemmis \& Taggart, komponen tindakan dan observasi dijadikan satu kesatuan karena keduanya merupakan tindakan yang tidak terpisahkan dan terjadi dalam waktu yang sama (Wiriatmojo, 2005:66). Empat komponen ini pada masing-masing siklus dapat dilihat pada gambar berikut ini: 


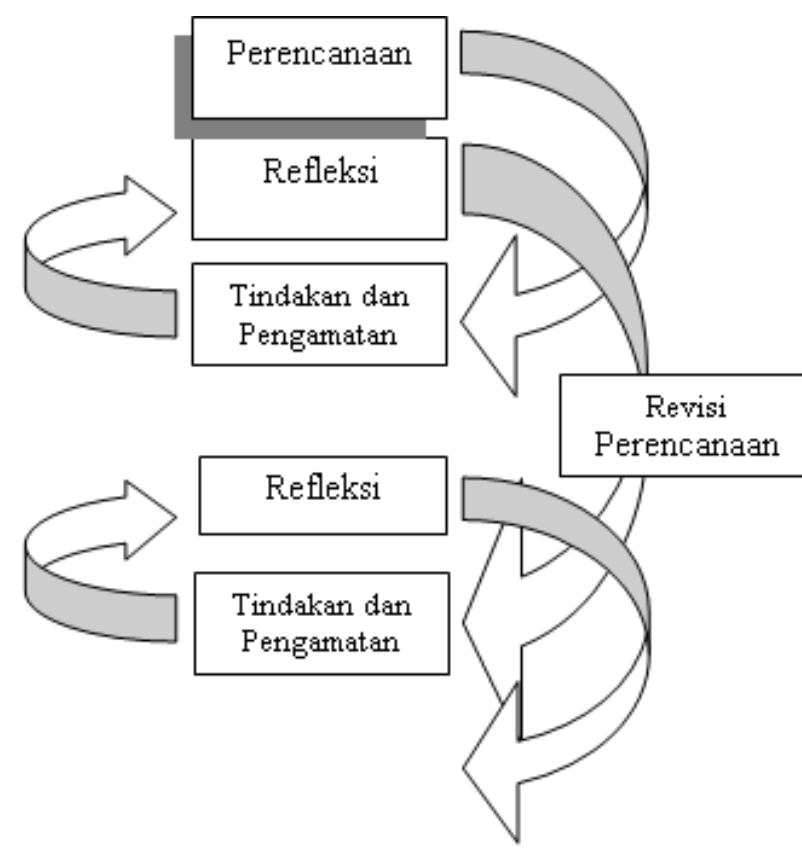

Bagan 1 : Model Spiral Wiriatmodjo, 2005

Penelitian ini dilakukan di SMP Negeri 1 Jabung Kabupaten Malang. Penelitian ini akan dilaksanakan di kelas VIII G pada semester genap tahun 20142015 yang berjumlah 32 siswa, terdiri atas 13 siswa laki-laki dan 19 siswa perempuan. Instrumen yang digunakan dalam penelitian ini adalah: Rencana Pelaksanaan Pembelajaran, Lembar Kerja Siswa, Lembar tes, Lembar observasi guru dan siswa, Pedoman wawancara, Dokumentasi, Format cacatan lapangan, Format penilaian kemampuan berfikir dan aktivitas siswa.

Data yang diperlukan dalam penelitian ini meliputi data keterlaksanaan pembelajaran dengan model problem solving, berfikir kritis, dan aktivitas siswa.pemerolehan sumber data diperoleh dari guru dan siswa.
Tabel 1. Data dan Sumber Data Penelitian

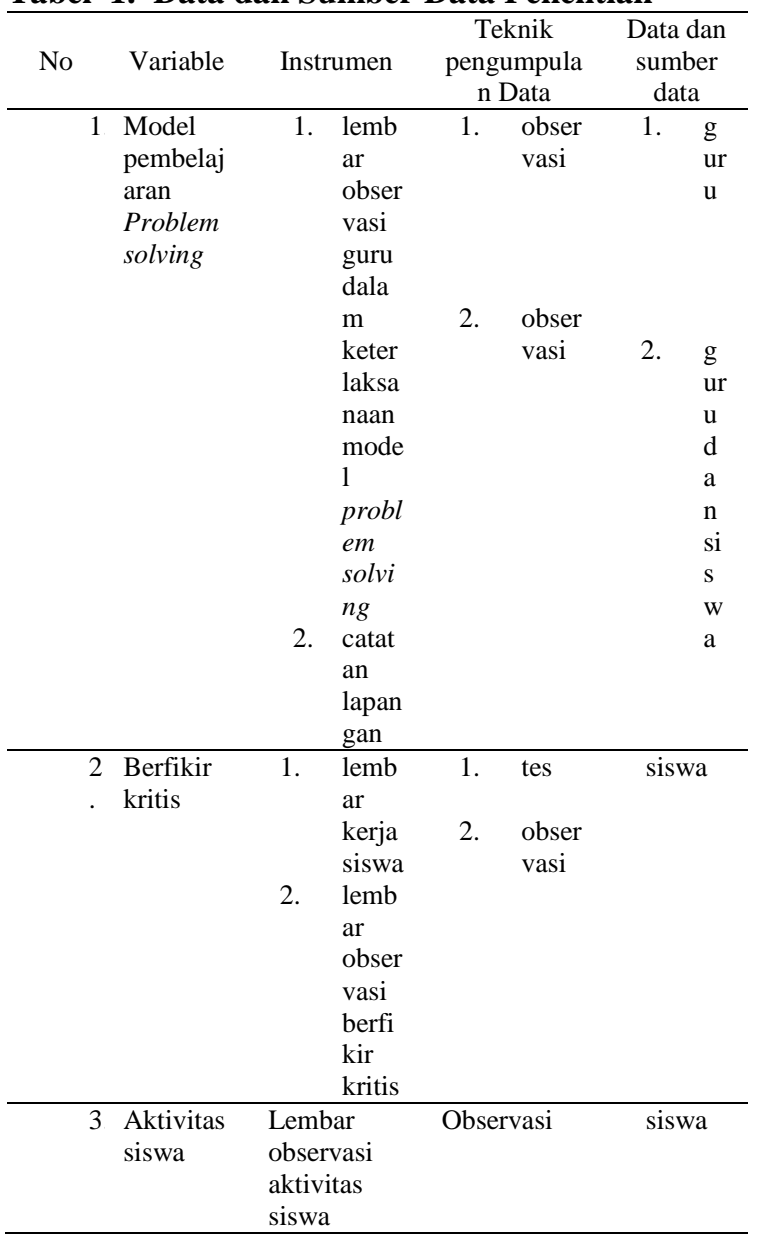

Prosedur pengumpulan data yang digunakan dalam penelitian ini adalah pengamatan (observasi), tes, wawancara, dokomentasi, dan catatan lapangan.

Analisis dalam penelitian ini dilakukan terhadap kemampuan berfikir kritis, observasi, dokumentasi.Analisis data dilakukan sekali dalam setiap siklus, dalam menganalisis menggunakan statistik sederhana,yaitu :

1. Keterlaksanaan pembelajaran problem solving

lembar observasi memuat indikator yang harus tampak pada pembelajaran problem solving dan sebagai standar ketuntasan yaitu $70 \%$. Data kemudian diolah sehingga diperoleh presentasi dengan rumus.

$\%$ keterlaksanaan pembelajaran $=$ $\frac{\sum \text { indikator keterlaksanaan }}{\sum \text { seluruh indikator }} \times 100 \%$ 
2. kemampuan berfikir kritis

data hasil observasi memuat butir-butir kemampuan berfikir kritis yang harus tampak pada proses pembelajaran dan masingmasing butir diskor dengan ketuntasan $70 \%$. Data berupa skor kemudian diolah sehingga dipresentasekan dengan rumus.

$\%$ kemampuan berfikir $=$ $\frac{\text { skor yang diperoleh }}{\text { skor maksimal }} \times 100 \%$

3. aktivitas belajar Menurut Krishannanto (2009:-), untuk mengetahui aktivitas belajar siswa melalui instrumen observasi dengan indikator yang muncul sebagai berikut :

a) memperhatikan apa yang disampaikan guru;

b) menjawab pertanyaan guru;

c) mengerjakan LKS yang diberikan guru;

d) bekerja sama dengan teman satu kelompok;

e) mendiskusikan masalah yang dihadapi dalam kegiatan belajar mengajar;

f) bertukar pendapat antar teman dalam kelompok;

g) mengambil keputusan dari semua jawaban yang dianggap benar;

h) mempresentasikan jawaban di depan kelas;

i) merespon jawaban teman;

Bobot penskoran dalam menghitung aktivitas siswa dalam belajar pada setiap indikator yaitu :

skor $1=$ kurang aktif

skor 2 = cukup aktif

skor $3=$ aktif

skor $4=$ sangat aktif

Nilai presentase dari setiap penskoran dengan jumlah keseluruhan indikator ada 9 indikator.

Jumlah maksimum kreteria kurang aktif $=9$

jumlah maksimum kreteria cukup aktif $=18$ jumlah maksimum kreteria aktif $=27$

jumlah maksimum kreteria sangat aktif $=36$

jumlah nilai aktivitas siswa $(\%)=$ indikator kegiatan yang muncul

jumlah maksimum pada kreteria penskoran $X 100 \%$

\section{Siklus I \\ Siklus I-Pertemuan I}

Pembelajaran yang dilaksanakan pada siklus I memberikan informasi kemampuan berfikir kritis siswa dalam memecahkan masalah dengan tahap-tahap melalui pengkajian masalah, interprestasi masalah, penyelesaian masalah dan pengambilan keputusan. Pada tahap kemampuan pengkajian masalah secara klasikal memperoleh jumlah skor 303( $63 \%$ ) dari jumlah skor 480. Pada kemampuan interprestasi masalahsecara klasikal memperoleh jumlah skor 262 $(55 \%)$ dari jumlah keseluruhan yaitu 480.Pada tahap penyelesaian masalah secara klasikal memperoleh jumlah skor 297(62\%) dari jumlah keseluruhan yaitu 480. Pada kemampuan pengambilan keputusan secara klasikal memperoleh jumlah skor 178 (56\%) dari jumlah keseluruhan 320 .

Secara keseluruhan perolehan skor berfikir kritis yaitu 1889 dengan ratarata presentase dalam aspek pengkajian masalah, interprestasi masalah, penyelesaian masalah dan pengambilan keputusan adalah 59\% . Hasil ini dipengaruhi karena beberapa faktor antara lain siswa kurang terbiasa dalam mengidentivikasi masalah, siswa belum runtut dalam menuliskan hal-hal penting dari tampilan media pembelajaran, siswa masih kesulitan dalam menentukan hipotesis, siswa kurang paham apa yang dimaksud dengan teori, sumber belajar siswa yang masih terbatas, siswa belum terbiasa dalam berfikir kritis, guru masih canggung dalam berinteraksi dengan siswa, terdapat siswa yang tidak masuk 
yang tidak ada keterangan yang menyebabkan tidak mendapatkan nilai.

Nilai hasil keseluruhan dari aktivitas siswa kelas VIII $G$ dalam kegiatan belajar mengajar diperoleh berdasarkan hasil penjumlahan skor keseluruhan dari setiap indikator yang didapat. Berikut ini merupakan hasil pengamatan aktivitas belajar siswa pada saat proses pebelajaran berlangsung.

Tabel 2. Aktivitas Belajar Siswa Pada Siklus I Pertemuan 1

\begin{tabular}{|l|c|}
\hline \multicolumn{1}{|c|}{$\begin{array}{c}\text { Aktivitas } \\
\text { Siswa }\end{array}$} & $\begin{array}{c}\text { Prosentase Nilai } \\
\text { aktivitas Siswa Siklus } \\
\text { I Pertemuan 1 }\end{array}$ \\
\hline Sangat aktif & $18,18 \%$ \\
\hline Aktif & $27,27 \%$ \\
\hline Cukup aktif & $54,54 \%$ \\
\hline Kurang aktif & - \\
\hline Jumlah & $100 \%$ \\
\hline
\end{tabular}

Hasil nilai prosentase dari setiap penskoran berdasarkan jumlah indikator keseluruhan ada 9 butir dengan perolehan kreteria keaktifan siswa selama proses pembelajaran pada kelas VIII G SMP Negeri 01 Jabung yaitu : sangat aktif $18,18 \%$, aktif $27,27 \%$, dan cukup aktif $54,54 \%$. Sedangkan keterlaksanaan pembelajaran berdasarkan 23 indikator yang diwajibkan diperoleh 18 skor keterlaksanaan sehingga diperoleh jumlah prosentase keseluruhan $78 \%$.

\section{Siklus I - Pertemuan II}

Kegiatan pembelajaran yang telah dilakukan dalam siklus I pertemuan ke 2 diperoleh hasil dari kemampuan berfikir kritis siswa melalui pengkajian masalah, interpretasi masalah, penyelesaian masalahdan pengambilan keputusan secara klasikal memperoleh jumlah skor $374(78 \%)$ dari jumlah keseluruhan yaitu 480. Pada kemampuan intepretasi masalah secara klasikal memperoleh jumlah 309 (64\%) dari jumlah keseluruhan yaitu 480.Pada kemampuan penyelesaian masalah secara klasikal memperoleh jumlah skor 304 (64\%) dari jumlah keseluruhan yaitu 480.Sedangkan pada kemampuan pengambilan keputusan secara klasikal memperoleh jumlah skor $216(68 \%)$ dari jumlah keseluruhan 320.

Berdasarkan hasil yang diperoleh tersebut maka didapatkan rata-rata kemampuan berfikir siswa dalam aspek pengkajian masalah, intepretasi masalah, penyelesaian masalah, dan pengambilan keputusan adalah 2189 (68\%), sehingga nilai yang diperoleh belum mencapai batas ketuntasan yang direncanakan yaitu $70 \%$. Hal ini dipengeruhi oleh beberapa faktor anatara lain, yaitu : a) siswa kesulitan dalam dalam membedakan judul dengan permasalahan yang disajikan oleh guru; $b$ ) siswa belum terbiasa dalam merumuskan hipotesis; c) buku sumber yang sangat terbatas untuk mencari cara mengatasi permasalahan yang adadibuku untuk dibandingkan dengan cara mengatasi permasalahan berdasarkan pemikiran siswa; dan d) terdapat satu siswa yang tidak masuk dengan tidak ada keterangan. Sedangkan pada siklus I pertemuan II keterlaksanaan pembelajaran model problem solving diperoleh skor 20 dari jumlah 23 indikator yang diwajibkan dengan perolehan prosentase $87 \%$.

Pada siklus I pertemuan 2 dapat diketahui nilai hasil keseluruhan dari aktivitas siswa kelas VIII G dalam kegiatan belajar mengajar diperoleh berdasarkan hasil penjumlahan skor keseluruhan dari setiap indikator yang didapat. Berikut ini merupakan hasil pengamatan aktivitas belajar siswa pada saat proses pembelajaran berlangsung.

Tabel 3. Aktivitas Belajar Siswa pada siklus I pertemuan 2

\begin{tabular}{|l|c|}
\hline \multicolumn{1}{|c|}{$\begin{array}{c}\text { Aktivitas } \\
\text { Siswa }\end{array}$} & $\begin{array}{c}\text { Prosentase Nilai } \\
\text { aktivitas Siswa Siklus } \\
\text { I Pertemuan 2 }\end{array}$ \\
\hline Sangat aktif & $43,47 \%$ \\
\hline Aktif & $39 \%$ \\
\hline Cukup aktif & $17,39 \%$ \\
\hline Kurang aktif & - \\
\hline Jumlah & $100 \%$ \\
\hline
\end{tabular}


Berdasarkan hasil aktivitas belajar siswa pada siklus I pertemuan 2 diperoleh nilai prosentase dari setiap penskoran berdasarkan jumlah indikator keseluruhan yang berjumlah 9 butir dengan perolehan kreteria keaktifan siswa selama proses pembelajaran pada kelas VIII G SMP Negeri 01 Jabung sebagai berikut : Sangat aktif 43,47\%, aktif 39\%, dan cukup aktif $17,39 \%$.

\section{Refleksi}

Pada siklus I dalam pembelajaran problem solving siswa kurang antusias dalam mengikuti pembelajaran, psiswa belum terbiasa untuk berpikir kritis, siswa kurang percaya diri dalam mempresentasikjan hasil pekerjannya.

\section{Siklus II}

Pada siklus II hasil yang didapat dalam kegiatan belajar siswa untuk kemampuan berfikir kritis siswa antara lain pengkajian masalah, interpretasi masalah, penyelesaian masalah, dan pengambilan keputusan . Pada tahap kemampuan pengkajian secara klasikal memperolah 361(75\%) dari jumlah keseluruhan yaitu 480. Pada kemampuan intepretasi masalah secara klasikal memperoleh jumlah skor $328(68 \%)$ dari jumlah keseluruhan yaitu 480.Pada kemampuan menyelesaiakan masalah secara klasikal diperoleh 337 (70\%) dari jumlah skor keseluruhan yaitu 480.Dan pada kemampuan pengambilan keputusan secara klasikal diperoleh jumlah skor 232 (73\%) dari jumlah keseluruhan yaitu 320 .

Berdasarkan paparan datatersebut dapat diketahui bahwa kemampuan berfikir kritis dalam aspek pengkajian masalah, intepretasi masalah, penyelesaian masalah dan pengembilan keputusan adalah 2280 (71 \%).Terjadi peningkatan secara kontinu dari pertemuan sebelumnya yang dipengaruhi beberapa faktor yaitu siswa terbiasa dalam berfikir dalam memecahkan masalah dan mampu menemukan pemecahan masalah dari pemikiran sendiri maupun dari buku
sumber.Pada keterlaksanaan pembelajaran problem solving diperoleh skor dari 23 indikator yang diwajibkan ialah 21 dengan presentase $91 \%$.

Nilai hasil keseluruhan dari aktivitas siswa kelas VIII $G$ dalam kegiatan belajar mengajar diperoleh berdasarkan hasil penjumlahan skor keseluruhan dari setiap indikator yang didapat. Berikut ini merupakan hasil pengamatan aktivitas belajar siswa pada saat proses pebelajaran berlangsung.

Tabel 4 Aktivitas Belajar Siswa Pada Siklus II

\begin{tabular}{|l|c|}
\hline \multicolumn{1}{|c|}{$\begin{array}{c}\text { Aktivitas } \\
\text { Siswa }\end{array}$} & $\begin{array}{c}\text { Prosentase Nilai aktivitas } \\
\text { Siswa Siklus II } \\
\text { Pertemuan 1 }\end{array}$ \\
\hline Sangat aktif & $75 \%$ \\
\hline Aktif & $18,75 \%$ \\
\hline Cukup aktif & $6,25 \%$ \\
\hline Kurang aktif & - \\
\hline Jumlah & $100 \%$ \\
\hline
\end{tabular}

Hasil Nilai prosentase dari setiap penskoran berdasarkan jumlah indikator keseluruhan ada 9 butir dengan perolehan kreteria keaktifan siswa selama proses pembelajaran pada kelas VIII G SMP Negeri 01 Jabung sebagai berikut : sangat aktif $75 \%$, aktif $18,75 \%$, dan cukup aktif $6,25 \%$.

Dengan adanya peningkatan yang berbeda pada setiap siklus dari siklus I dan siklus II dengan persentase akhir $71 \%$ sudah berhasil dengan baik walaupun selisih tipis dengan target yang diinginkan yaitu $70 \%$. Hal ini tidak dilanjutkan dengan tindakan siklus berikutnya karena keterbatasan waktu yang menjadi hambatan, karena dari sekolah berbenturan dengan tryout kelas IX sehingga kelas yang dibuat penelitian tidak bisa masuk kelas.

\section{Model Pembelajaran Problem Solving Dapat Meningkatkan Ketrampilan Berfikir Siswa Pada Mata Pelajaran PKn Kelas VIII Di SMP Negeri 1 Jabung}


Pembelajaran menggunakan model problem solving dilaksanakan dengan beberapa langkah antara lain: 1) siswa diorientasikan dengan adanya permasalahan yang disajikan oleh guru kemudian siswa menuliskan temuannya dibuku lalu guru memberikan LKS; 2) guru mengorganisasikan siswa untuk menganalisis masalah dari berbagai sumber dengan kegiatan siswa berdiskusi dengan temannya dan memahami masalah; 3) siswa merumuskan alternative pemecahan masalah dengan cara memberikan ide, gagasan, pendapat dalam mencari solusi secsarsa mandiri, dan dilanjutkan memilih salah satu solusi pemecahan masalah berdasarkan hasil diskusi; 4) pengujian hipoteis dengan mengaitkan teori dengan cara membandingkan ide dan gagasan siswa dengan teori yang ada dibuku; 5) merumuskan kesimpulan dari hasil pengujian hipotesis dengan kegiatan akhir membuat kesimpulan. Guru memberikan penguatan hasil kesimpulan siswa dengan cara melengkapi apa yang sudah disampaikan oleh siswa. Kegiatan pembelajaran menggunakan model problem solving sangat jelas memberikan kesempatan kepada siswa untuk mengeksplorasi, mengumpulkan dan menganalisis data secara lengkap untuk dapat memecahkan masalah yang dihadapi.

Berdasarkan hal tersebut maka penelitian ini menerapkan model problem solvingdalam kegiatan pembelajaran pendidikan kewarganegaraan di kelas VIII G SMP Negeri 1 Jabung. Penelitian ini dilaksanakan dalam 2 siklus, instrumen yang digunakan dalam menilai keterlaksanaan pembelajaran model problem solving menggunakan checklist.Hasil dari perolehan instrumen keterlaksanaan model problem solving pada siklus I pertemuan 1 adalah $78 \%$ pada pertemuan 2 diperoleh $87 \%$.Setelah dilakukan penyempurnaan dari hasil refleksi maka pelaksanaan pembelajaran model problem solving pada pertemuan II diperoleh prosentase 90\%.Dari paparan data tersebut jelas bahwa keterlaksanaan pembelajaran problem solving mengalami peningkatan.

Pelaksanaan pembelajaran model problem solvingberdampak pula terhadap kemampuan berfikir kritis siswa.Presentase kemampuan berfikir kritis siswa pada siklus I pertemuan 1 yaitu $59 \%$ dan pertemuan 2 yaitu $68 \%$ sehingga dapat disimpulkan telah mengalami peningkatan sebesar 9\%. Sedangkan kemampuan berfikir kritis siswa pada siklus II yaitu $71 \%$ sehingga dapat disimpulkan dari siklus 1 pertemuan 2 dan siklus 2 mengalami peningkatan sebesar 3\%.Data tersebut jelas mengambarkan bahwa penerapan model problem solving dapat meningkatkan kemampuan berfikir kritis siswa.

\section{Model PembelajaranProblem Solving Dapat Meningkatkan Aktivitas Siswa Pada Mata Pelajaran Pkn Kelas VIII Di SMP Negeri 1 Jabung}

Berdasarkan tahapan problem solving diperoleh hasil aktivitas belajar siswa, bahwa penerapan model pembelajaran problem solving berdasarkaninstrumen diperoleh hasil yaitu: 1) siswa diorientasikan dengan adanya permasalahan yang disajikan oleh guru kemudian siswa menuliskan temuannya dibuku lalu guru memberikan LKS; 2) guru mengorganisasikan siswa untuk menganalisis masalah dari berbagai sumber dengan kegiatan siswa berdiskusi dengan temannya dan memahami masalah; 3) siswa merumuskan alternative pemecahan masalah dengan cara memberikan ide, gagasan, pendapat dalam mencari solusi secsarsa mandiri, dan dilanjutkan memilih salah satu solusi pemecahan masalah berdasarkan hasil diskusi; 4) pengujian hipoteis dengan mengaitkan teori dengan cara membandingkan ide dan gagasan siswa dengan teori yang ada dibuku; 5) merumuskan kesimpulan dari hasil 
pengujian hipotesis dengan kegiatan akhir membuat kesimpulan. Guru memberikan penguatan hasil kesimpulan siswa dengan cara melengkapi apa yang sudah disampaikan oleh siswa.

Berdasarkan langkah problem solving diperoleh hasil dari pelaksanaan pembelajaran pada siklus I pertemuan 1 bahwaberdasarkan jumlah indikator keseluruhan ada 9 butir dengan perolehan kreteria keaktifan siswa selama proses pembelajaran pada kelas VIII SMP Negeri 01 Jabung sebagai berikut : sangat aktif $18,18 \%$, aktif $27,27 \%$, dan cukup aktif $54,54 \%$, hal ini disebabkan siswa kurang siap dalam menerima pelajaran, berdasarkan 9 indikator instrumen pengamatan (masih banyak yang belum terlaksana sehingga mempengaruhi pelaksanaan model problem solving dan pada siklus I pertemuan 2 setelah melakukan refleksi dan evaluasi pada siklus I dilakukan perbaikan terhadap kekurangan pada tahap sebelumnya dan diperoleh keaktifan siswa selama proses pembelajaran: sangat aktif $43,47 \%$, aktif $39 \%$, dan cukup aktif 17,39\%, hal ini dikarenakan adanya perbaikan pelaksanaan sehingga berdasarkan 9 indikator instrumen aktivitas siswa sudah banyak menunjukkan perubahan peningkatan kualitas belajar namun masih perlu perhatian dan perbaikan agar menghasilkan hasil aktivitas belajar yang baik. Sedangkan pada siklus 2 perolehan nilai prosentase keaktifan siswa diperoleh yaitu : sangat aktif $75 \%$, aktif $18,75 \%$, dan cukup aktif $6,25 \%$, hal ini berdasarkan 9 indikator aktivitas belajar siswa sudah terlaksanan dengan baik. Dari paparan data tersebut diperoleh paparan bahwa pada siklus I pertemuan 1 sangat aktif $18,18 \%$, pertemuan 2 sangat aktif $43,47 \%$ dan pada siklus II sangat aktif $75 \%$, berdasarkan hasil siklus I dan II keaktifitas siswa selama proses pembelajaran berlangsung dengan menggunakan model problem solvingmeningkat. Dari paparan hasil tersebut disimpulkan bahwa penerapan model pembelajaran problem solvingdapat meningkatkan aktivitas belajar siswa.

\section{KESIMPULAN DAN SARAN}

Penerapan Pembelajaran dengan model problem solving terbukti dapat meningkatkan kemampuan berfikir kritis siswa, hal ini terbukti dengan pemaparan data yang sebelumnya yang menunjukkan adanya peningkatan dalam kemampuan berfikir kritis siswa pada setiap pertemuan selama 2 siklus. Berdasarkan paparan data yang telah di sajikan menunjukkan bahwa kemampuan berfikir kritis siswa telah mengalami peningkatan secara kontinu. Aktifitas siswa dalam pembelajaran menggunakan model problem solving berdasarkan paparan data terbukti dapat membuat siswa lebih aktif dan kritis karena selama proses belajar siswa lebih terlibat langsung dalam pembelajaran. Peranan guru dalam pembelajaran dengan model problem solving dengan kreatif telah mengarahkan siswa untuk menggali pengetahuan dengan berinteraksi bersama temannya serta bertanya dan menjawab pertanyaan yang dimunculkan baik oleh guru maupun siswa, hal ini terbukti banyaknya siswa yang mengangkat tangan dan menjawab pertanyaan guru tanpa ditunjuk terlebih dahulu.

Berdasarkan hasil penelitian ini dapat diajukan beberapa saran yaitu: (1) bagi peneliti selanjutnya model problem solving dapat digunakan untuk mengetahui variabel lain misalnya motivasi berprestasi dan hasil belajar; (2) model pembelajaran problem solving selain dapat digunakan pada mata pelajaran PKn bisa diterapkan pada mata pelajaran lain misalnya mata pelajaran matematika, IPS, dan biologi.

\section{DAFTAR RUJUKAN}

\author{
Depdiknas. 2006. Contoh/ Model Silabus \\ Mata Pelajaran Pendidikan \\ Kewarganegaraan Sekolah \\ Menengah Pertama. Jakarta : BNSP \\ dan Depdiknas.
}


Ennis, R. 1992.Critical Thinking. What is it? Proceeding of the Forty- Eight Annual Meeting of The Philosophy of Education Society. Denver,

Hamalik, Omar. 2005. Proses Belajar Mengajar. Jakarta: PT Bumi Aksara

Hudojo, 2003. Pengembangan Kurikulum dan Pembelajaran Matematika, Common Textbook, (Malang: Jurusan Matematika, FMIPA)

Kemmis, W.C. \& Taggart, R.M. 1988. The Action Research Planer. Gulong Victoria: Deakin University press.

Krishannanto, D. 2009. Instrumen Aktivitas Belajar Siswa, (online), (http://tecnology

13.wordpress.com/2009/07/03/instru men-aktivitas-belajar-siswa/) diakses Maret 2015.

Polya, G. 1957. How to solve it. New

York: Douoleday
Rahyubi, 2012. Teori-Teori Belajar dan Aplikasi Pembelajaran Motorik. Bandung: PT. Remaja Rosdakarya

Sardiman, A.M. 2001. Interaksi Dan Motifasi Belajar Mengajar. Jakarta: PT Raja Grafindo Persada

Undang-Undang Nomor 20 Tahun 2004 tentan Sistem Pendidikan Nasional.

Widyani, N. 2013. Penggunaan Motode Problem Solving Dalam Pembelajaran PKN Untuk Meningkatkan Aktivitas dan Hasil Belajar Siswa Dikelas VIII.6 SMP Negeri 3 Banjar Kabupaten Buleleng. Undiksha

Wiriatmodjo, R. 2009. Metode PenelitianTindakan Kelas. Bandung: PT. Remaja Rosdakarya. 